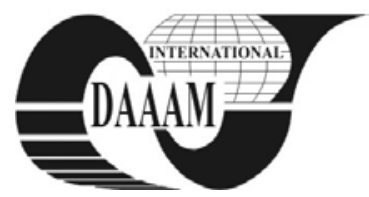

\title{
ENVIRONMENTAL SAFETY MANAGEMENT IN THE CONTEXT OF INNOVATIVE DEVELOPMENT OF ENTERPRISES
}

\author{
EGOROVA, O[lga]
}

\begin{abstract}
The author of the article focuses on the management solutions of industrial enterprises and goal-setting process aimed at ensuring environmental safety and sustainable development. The paper explains the necessity of taking environmental aspects into consideration when managing an industrial enterprise in order to achieve competitive, efficient and innovative production.
\end{abstract}

Key words: environmental safety, industrial enterprise, innovations

\section{INTRODUCTION}

Today the modern society is faced with a number of environmental issues. Most environmental issues have both local and global impact and have to be regulated on both national and international levels. Environmental safety issues should be especially addressed by enterprises in the light of the global economic crisis. A lot of industrial enterprises have put off their environmental and social projects, which may have negative consequences both for production and environment. Therefore, industrial enterprises have to adopt an environmental policy in order to ensure their environmental safety.

The aim of this paper is the analysis of the environmental safety management solutions in the industrial enterprises. The author's approach to eco decision-making is based on scientific sources analysis of social and economic solutions in the industrial practice and alternative approach to environmental decision-making. The results of the research described in this paper are aimed at formulating the mission of modern ecofriendly industrial enterprises, based on sustainable development. The next step of this research will be the analysis of industrial management solutions in Russia and preparation of the educational and consulting courses for managers, willing to improve the efficiency of the industrial eco-friendly production.

\section{ENVIRONMENTAL MANAGEMENT SYSTEM}

Environmental safety issues are often caused by poor management in an enterprise. It is necessary to use high-quality management resources, taking national traditions, mentality, values, quality and standards of living, development priorities into consideration. Implementation of innovative management strategies requires a sociological analysis of changes in society and management training (Klementyev \& Ribakov 2007). Feedback also plays a very important role in the functioning of the entire system of management. It can act as a staff motivator, making employees set higher goals, develop successful strategies and, consequently, achieve better results.

A new values system should be established at any enterprise that wants to solve its environmental problems and achieve sustainable, resource-saving and environmentally friendly development. Present environmental issues need to be reviewed in the context of management. Environmental management system provides a solution to organization of environmental issues through the use of available resources, allocation of responsibilities and regular evaluation of performance. It is necessary to supervise and manage enterprise's development, to maintain compliance with environmental legislation, to educate and involve all departments in the environmental protection process. Lean production and environmental management means assessing the risks and chances of prospective enterprise's development and developing an environmentally friendly development strategy. However, making management decisions requires taking into consideration the following environmental aspects:

- emphasis on the environmental protection;

- recognizing the latter as one of the most important values for a society;

- global societal interests' priority over individual interests (Peattie 1992).

B. Coddington approach describes environmental aspects more accurately, focusing on such issues as environmental outlook (the effects of societal actions on environment) and environmental liabilities (the transformation of the enterprise into a system, controlling all arising environmental problems (Coddington 1993). Enterprises have to create conditions for environmental protection, development of environmentally friendly and highly competitive products, increase sales, while receiving additional profits at the expense of lean production, as well as dispose of all industrial waste according to environmental legislation.

Protecting environment is an important issue for any enterprise. Thus, enterprises have to take public responsibility and participate in the process of matching the interests of economy and environment to each other. This is called social and ethical basis of management: combining producers' consumers', society's and environment's interests. Management decisions are analyzed according to the changes in the market philosophy, i.e. transition to the sustainable development ethics.

Environmental management should be considered as the basic move towards sustainable development of the enterprise. This leads to the fact, that environmental policy is one of the most important management aspects. Environmental policy is the basis for establishing goals and objectives of the enterprise. Principles of environmental policy must be clear to all stakeholders of the enterprise. The former should be regularly evaluated and reviewed to ensure that it reflects the current situation in the enterprise.

The enterprise has to establish certain environmental parameters aimed at managing performance and production of the enterprise. Moreover, the latter should control the enterprise's compliance with the chosen parameters. Such measures are vital for identifying the major environmental aspects of the enterprise which have a significant influence on the environmental situation.

There is a list of requirements that an enterprise's environmental policy should follow (Aleksyeyeva \& Khabarova 2002). 


\begin{tabular}{|c|c|c|}
\hline \multirow[b]{2}{*}{$\begin{array}{c}\text { Principles of } \\
\text { environmental policy }\end{array}$} & \multicolumn{2}{|c|}{$\begin{array}{c}\text { The use of environmental } \\
\text { policy principle (\%) }\end{array}$} \\
\hline & $\begin{array}{l}\text { Leading } \\
\text { industrial } \\
\text { enterprises in } \\
\text { the world }\end{array}$ & $\begin{array}{c}\text { Leading } \\
\text { industrial } \\
\text { enterprises in } \\
\text { Russia } \\
\end{array}$ \\
\hline $\begin{array}{l}\text { Minimizing the negative } \\
\text { impact on the } \\
\text { environment }\end{array}$ & 85 & 76 \\
\hline $\begin{array}{l}\text { Compliance with } \\
\text { environmental legislation }\end{array}$ & 77 & 64 \\
\hline $\begin{array}{l}\text { Development } \\
\text { distribution of and } \\
\text { enterprise's } \\
\text { environmental reports }\end{array}$ & 42 & 18 \\
\hline $\begin{array}{l}\text { Transparency of the } \\
\text { enterprise's } \\
\text { environmental reports }\end{array}$ & 80 & 29 \\
\hline $\begin{array}{l}\text { Employees participation } \\
\text { in the enterprise's } \\
\text { environmental activities }\end{array}$ & 67 & 64 \\
\hline $\begin{array}{l}\text { Reasonable and efficient } \\
\text { resources allocation }\end{array}$ & 52 & 41 \\
\hline $\begin{array}{l}\text { Environmental policy } \\
\text { efficiency }\end{array}$ & 66 & 24 \\
\hline $\begin{array}{l}\text { Negative environmental } \\
\text { impact prevention }\end{array}$ & 50 & 41 \\
\hline $\begin{array}{l}\text { Enterprise’s participation } \\
\text { in } \quad \text { environmental } \\
\text { activities }\end{array}$ & 41 & 12 \\
\hline $\begin{array}{l}\text { Cooperation with other } \\
\text { enterprises and society } \\
\text { concerning } \\
\text { environmental } \\
\text { issues }\end{array}$ & 81 & 47 \\
\hline $\begin{array}{l}\text { Ensuring employees' and } \\
\text { society's health and } \\
\text { safety }\end{array}$ & 44 & 47 \\
\hline $\begin{array}{ll}\text { Environmental risks } \\
\text { management }\end{array}$ & 28 & 62 \\
\hline $\begin{array}{l}\text { Environmental } \\
\text { leadership }\end{array}$ & 7 & 12 \\
\hline $\begin{array}{l}\text { Managers’ } \\
\text { environmental } \\
\text { awareness, } \\
\text { responsibility }\end{array}$ & 37 & 8 \\
\hline
\end{tabular}

Tab. 1. Use of environmental policy principles by the leading industrial enterprises (\%)

Analysis of the list of principles, which shows whether the enterprise has efficient environmental policy or not, according to ISO 14000 standards, provided me with an opportunity to research the level of use of these principles worldwide and in Russia. Only a few enterprises in Russia follow the environmental principles, however the development of sustainable and environmentally friendly market in Russia has already begun and a lot of Russian managers have started using innovative approach to environmental management.

Environmental policy of industrial enterprises also includes the concept of "social responsibility". The European Commission identifies the term a social responsibility as "a concept whereby companies integrate social and environmental concerns in their business operations and in their interaction with their stakeholders on a voluntary basis (Biltgein 2004)", and the advisory group of experts of the International
Organization for Standardization (International Standards Organization - ISO) - as "a balanced approach for organizations to address economic, social and environmental issues in a way that aims to benefit people, communities and society" (Leonard \& McAdam 2003).

Any enterprise which identifies itself with society and feels a responsible not only for its present condition, but also for its future, including national culture, health and welfare of future generations can be called socially responsible.

Social responsibility of business in the context of environmental security means complying with the requirements of environmental legislation when conducting economic activities. This also applies to the transparency of all environmentally relevant information. Moreover, the enterprise should implement a number of activities aimed at reducing anthropogenic impacts on the environment.

\section{CONCLUSION}

Environmental safety management that is aimed at protecting the environment is an important aspect of industrial enterprises' activities. In the context of innovative development enterprises should take responsibility for the negative impact of their industrial activities. Socio-ethical nature of environmental safety management has to combine the interests of producers, consumers, society and environment. It is necessary to manage and control the production by means of complying with the environmental legislation, participating in various environmental activities and creating an innovative values system, which includes environmental issues. Managers should also take into consideration all the environmental aspects of business in order to achieve innovative, energy-efficient, competitive and environmentally friendly production

\section{REFERENCES}

Aleksyeyeva, Y., Khabarova, E. (2002). Formation of the environmentally friendly market in Russia. Practical marketing, No 8., (2002) pp. 18-22

Biltgein, F. (2004). Social responsibility of enterprises. View from Luxembourg, RAGS, Moscow

Coddington, W. (1993). Environmental Marketing: Positive Strategies for Reaching the Green Consumer, McGrawHill, New York

Egorova, O.S. (2010). Socio-managerial mechanisms, affecting sustainable development of the ecological goods and services market. Proceedings of VIII International scientific and practical conference "Natural and resource potential, ecology and sustainable development of Russian regions", Penza, pp. 48-51, RIO PGSHA, Penza

Egorova, O.S. (2010). Values system of managers as an indicator of modern Russian society development. Proceedings of International scientific and practical conference "Management: administration in social and economic systems”, Penza, pp. 104-107, RIO PGSHA, Penza

Klementyev, D.S., Ribakov, M.V. (2007) Sociology of management. Sociological research, No 5., (2007) pp. 153154

Kobylyatskiy, N.G. (2005) The question of scientific paradigm formation: Publications overview (sociology of management). Sociological research, No 4., (2005) pp. 6468

Leonard, A., McAdam, R. (2003). Corporate social responsibility, Quality Progress, Moscow

Peattie, K. (1992). Green Marketing, The M \& handbook series, London 